The Jocrval last week, has advised the rejection of the vessel owing to the cases of typhoid occurring among its crew.

The Montreal Maternity Hospital has just been given $\$ 15,000$, Sir William Maedonald and Messrs. Ross and Angus contributing $\$ 5000$ equally. Lord Strathcona, who has already given $\$ 10.000$, promises another $\$ 1,000$ if nine others will donate a similar amount.

IN CONNECTION with the outbreak of typhoid fever in Westmount, a suburb of Montreal, it is stated that a milk-dealer is confined in the Western Hospital there with the disease, contracted from the milk which he himself had supplied.

TuE Fol.r of treating their own children by parents was aptly illustrated in Hamilton this week. A child 4 years old was attacked with convulsions, and the mother, who was lying ill in bed, instructed her husband to place it in a hot batl. The result was that it was so severely scalded that it died two or three hours later.

OF TIIE $\$ 30,000$ indebtedness of the Victoria Hospital for Sick Children, Toronto, $\$ 25,000$ has already been subscribed, largely through the generosity of the fraternal organizations throughout Ontario. It is expected that the balance will be made up by the end of February.

For intimidating the medical health officer of Toronto in connection with that officer's examination of the city's firemen, recently, a citizen was convicted in the assize court, but allowed to go on suspended sentence after his attorney had made a. public apology to the health officer.

\section{NURSING-AT-HOME MISSION.}

The twelfth annual report of the Toronto Nursing-at-Home Mission shows that during the past year 374 women, 26 girls, 26 infants, 24 boys and 14 men were treated. Out of this number 38 were sent to the various hospitals, 30 deaths took place, and 7157 visits were made. All told, 2858 patients were treated and 3027 preseriptions issued. The work is carried on among all classes and conditions of people, regardless of race or creed.

\section{A CaNadian hospital Ship, THE "MAPLe Leaf."}

Major Napier Keefer, Toronto, of the Bengal Army, retired, has come forward with a project and the offer of $\$ 1000$ toward the equipment and maintenance of a hospital ship for the Canadians now at and on their way to South Africa. He is of the opinion that if Canada could fit out and equip such a vessel, the gift to the Imperial authorities would be greatly appreciated. Canada will very soon have upward of 3000 men in the field, when the Stratheona Horse, which the Canadian High Commissioner, Lord Strathcona, has so patriotically offered to the Home Government at his own expense, shall have been enrolled and dispatched; and the sick and wounded from this force might be given a prior claim for admission in this hospital ship.

\section{LODGE PRAC'TICE IN VICTOKIA, $\mathrm{B}$. C.}

As announced in last week's Journal, the physicians of Vic. toria have set their faces hard against lodge contract practice, but they still have the lodges to reckon with, and it will be interesting to follow the actions of the interested parties as to the outcome of the struggle. Following fast on the declaration of professional independence by our confrères in the West, comes the news that the representatives of some seventeen fraternal organizations in that city have held a mass meeting at which the doctors came in for much abuse, not unmixed with threats of what the lodges would do if the physicians did not come to time and mend the error of their ways. It was decided that an advertisement should be inserted in the provincial papers for two or more qualified physicians. The idea of the fraternal societies is to form cottage hospitals throughout the eity and have their own special physicians paid by salary, whose further duty it shall be to attend only to the families of fraternals. (See also p. 242.)

\section{SMALLPOX IN NEW BRUNSWICK.}

The dread disease has made its appearance in and around Campbellton and Moncliton, and there are now three provinces in Canada having centers for the spreal of infection. The local Board of Health is arranging for a general vaceination, and as the sections in Quebee and New Brunswick infected are contiguous, and traversed by the Intercolonial Railway, every precaution will be taken to prevent the spread of the disease along the railway line. All employees on trains and at stations, whose duties bring them into relation with the traveling public, have been ordered to be vaccinated, and arrangements have been made for the disinfection of all passenger cars. It is thought that it would be a wise precaution to vaceinate all the members of the Second Canadian Contingent, as they will he passing through the infected districts on their journey to Halifax, whence they embark for Cape Town.

ontario statistics.

The death-rate for this province last year was a trifle over that for 1898. In 1899 there were 23,426 deaths reported to the Provincial Board of Health, making a percentage of 10.5 , against 11 per 1000 for $189 \mathrm{~s}$. Consumption caused the death of more persons than all other contagious diseases put together, 2315 dying from tuberculosis alone. Deaths from the other contagious dizeases were: scarlet fever, 214; diphtheria, 363; measles, 43; whooping-cough, 90 ; typhoid fever, 381 . During December alone 99.75 per cent. of the population reportedthe largest on record. This represented 746 municipalities, the total deaths for the month being 1843. Of these consumption was responsible for $15 \%$. Marriages appear to be on the increase in the province. During 1898 the total number was 15,293 , an increase of 381 over the previous year. In Toronto alone there were 1696 marriages in 1898 , or an increase of 195 over the previous year.

ROYAL VICTORIA HOSPITAL, MONTREAL.

The annual meeting of the governing board of this institution took place last week, the election of officers for the ensuing year resulting in the selection of the Hon. R. B. Angus as president. The report of the superintendent showed that dur. ing the past year 2537 patients have been admitted to the hospital. Of these 1545 were free patients, 656 public ward patients paid at the rate of 50 cents per day, and 336 private. The increase over the previous year has been 256. On Jan. 1, 1899 , there were 133 patients remaining from 1898, and during the year 2543 have been discharged, of whom 1530 were well. 613 improved, 119 unimproved, 140 not treated, 111 died, and 157 remained on Dec. 31, 1899. Of the 111 deaths, 31 took place within forty-eight hours of admission, the death-rate for the year being 4.41 per cent. The highest number of patients in the hospital on any one day was 200 and the lowest 134 . In the out-patient department there were 16,721 consultations, as against 14,681 for the previous year, the increase being attributed to the opening of the new laryngologic department. The medical consultations were 6228 ; surgical, 5218 ; eye and ear, 2685 ; nose and throat, 1527 ; and diseases of women, 1963. The ordinary income for the year was $\$ 113,892.71$, the expenditure amounting to $\$ 94,851.64$, the balance being applied toward che new out-patient department.

\section{Correspondence.}

\section{Medical Practice in the Philippines.}

Manira, P. I. Dec. 12, 1899

To the Editor:-This is a difficult place in which to put anything into literary form, one being in a sweat-bath most of the time, and having to stop every few minutes to wipe one's hands and face.

\section{PRACTICE IN MAXILA.}

The old Spanish law, under which we are administering the civil gorernment here, required the passing of an examination for dentists and veterinarians, but none for physicians, who were only required to have a diploma, to register and pay an annual tax of $\$ 50$ to $\$ 150$, according to supposed income, by which they were classified. There is no field here for American physicians, for several reasons. In the first place the fees are too small. I was called once to an American house where 1 had been attending the family, and found a native physician there, sent for in energency by the servants. He withdrew as soon as I arrived, but $I$ asked him what fee he expected. His reply was that the usual honorarium was dos pesos, equal to $\$ 1$ in our money. He is a mestizo of good professional standing and education, a graduate of the University of I3arcelona, Spain, in medicine, and ret he only expected $\$ 1$, gold, for an emergency call to an American family. Among his own people 
he would probably expect an average of 50 cents, Mexican, equal to 25 cents in gold, for each visit. In the next place, the people who pay for their medical service are well-to-do mestizos, and they prefer their own race, who speak both Spanish and Tagalog. and use remedies with which the people are familiar. There are plenty of such men here, who have been educated first at the local medical college, which is connected with the University of Manila, and have taken a supplementary degree in Spain. There are also several first-class English physicians here, who attend their own nationality as well as other foreign ers, and have a considerable clientele among the wealthy natives. Several American physicians have tried to settle here during the last year; some after leaving the Army or Red Cross organization, others having come out specially for that purpose. With one or two exceptions they have failed to establish a practice and have gone home. Several of them told me that they could not do anything except to "fake it" among our soldiers, on venereal disease, and preferred to quit rather than do so.

\section{A MEDiCAL GatHERING.}

As to what the medical men are doing here elinically, there is not much to say. There is no opportunity for meeting one another regularly, and we of the army are worked so continuously that we have no time in which to look each other up. We had a pleasant meeting on the hospital ship Relief, a short time ago, at the invitation of Major Perley, the surgeon in charge. A paper was read and discussed to some extent. This is the only occasion on which we have met for sush purposes since the occupation.

\section{HEALTH OF THE PHILIPPINES.}

Manila is not an unhealthy eity. It has a most excellent water-supply, the gift of one of the former Spanish GovernorsGeneral, who left a large private fortune for this purpose, requiring that the water should be free to all citizens. There are public hydrants in every street, even far out in the suburbs, and no one pays a cent for water obtained therefrom. The only water-rates are paid for service inside houses, and those who don't wish to have the service laid can employ Chinese watercarriers to fill their water-jars daily, carrying the water from the public hydrants. When this water is boiled and filtered, as is commonly done by Americans, it leaves nothing to be desired in this respect. Out on the lines, where the men have to drink what water they can get, there is much malarial and other water-borne affections; but in the city it is nearly always one's own fault if sickness comes, speaking generally. If the cases of wounds and injuries, venereal affections, and bowel troubles due to excess or carelessness in eating and drinking, were eliminated from the sick reports of the army, during the time when it lay here in Manila, there would have been but little left of the sick-lists. But we have had two armies of unseasoned recruits to deal with, and just as soon as the first army began to know what should be aroided to keep in good health, it had to go home to be mustered out, and the second one of recruits came to go through the same experience. On the lines the case is different, of course. Rough food, roughly prepared, poor water, and heat, prostrate many. Convalescence from any disease is very slow in this climate; and the shortest fever leaves the patient very weak for a long time.

NATURE OF THE FEvers.

The fevers are not malarial in most cases, as quinin does not control them; but they usually correspond to the forms of continued fever .which Manson treats in his "Tropical Diseases," under the title of "Unclassed Fevers of the Tropics." We have had a good deal of typhoid, and it has been of a severe type, and very fatal. One case now going on under my care in a woman, began four weeks ago with a temperature of $105.5 \mathrm{~F}$. For three days I used quinin sulphate, bisulphate, and hydro. chlcrate in daily doses of 30 grains, given between 6 a.m. and $12 \mathrm{~m}$., and found the temperature at 105.5 every evening. Then I dropped quinin and had a blood-test made, which showed a well-marked Widal reaction. Soon abdominal symptoms developed and the ease settled down into regular typhoid, but today the fever remains at 100 minimum and 102 maximum, after more than four weeks of continued fever. There are good points about the ease, however, which give me great faith in the ultimate recovery. There have been no mental symptoms, the tongue is always moist and clean, and the strength is well sustained on two quarts of milk a day. Whenever I check the number of stools by an opiate, the temperature immediately rises and goes to $104 \mathrm{~F}$.

DHOBIE ITCH.

One form of skin disease has given us much tronble, the socalled "Dhobie Itch;" a ring-worm affection which prefers the crotch and the axillæ in most cases, and is very obstinate in the field. Patients in the eity soon get rid of it by the help of local germicides, especially ehrysarobin ointment, but when it is neglected, as must of necessity occur in the field, it often affects the cellular tissue below the skin and causes a severe cellulitis.

SYPHILIS NOT PREVALENT.

Syphilis, contrary to our expectations, is very seldom seen, but chancroids and chancroidal buboes are very common, and seem to be the prevailing form of venereal infection.

MORTALITY AMONG NATIVES.

Among the natives, the death-lists, which are published daily, show that most of the mortality occurs from convulsionsprobably infantile-and beri-beri. There are sometimes 14 or 15 deaths daily from each of these, to 1 or 2 or 3 from any other cause. The natives suffer from calentura, whch means any kind of fever, whenever a cool wind prevails, and they say themselves that when the north winds blow there is mucho infirmidad-much sickness.

In the army there have been three deaths which have been suspected to have been due to beri-beri; but this is doubtful, the disease being practically unknown here among Europeans or other white races. Multiple neuritis has been seen quite often among our men, but the particular form of neuritis named beri-beri is confined to the native population. In view of the outbreak a few years ago, in an insane asylum in Dublin, Ireland, we may expect to have it among our white prisoners in the local penitentiary, but it has not yet been seen there, which fact speaks well for the sanitary condition of the place.

Women and children do very well out here, in fact they have had less sickness proportionately, than any other class of our American population. This is partly explainable by the greater care taken by them as regards food, drink and exposure to the sun in the middle hours of the day.

This army has been magnificently and munificiently supplied with everything. There has been no breakdown in any department, and no want of anything essential to the care of the men, sick or well. The medical department has been highly praised by foreign officers visiting our hospitals. Captain S. S. Long, deputy assistant adjutant-general of the British Army, came here from Hongkong during the early operations, before the fall of Manila, and looked into every department of our service. On his return he published an article in the Journal of the United Service Institution in India, in which he said: "If the spirit of the troops was excellent, it was even surpassed by that of the medical branch, who; in spite of a defective transport and many other difficulties, always had their hospitals as complete and efficient as it was possible for human ingenuity to make thern. It speaks well for the skill of the department that they were completely successful in a large number of eases of abdominal wounds." You will find Captain Long's article reprinted in full, in the issue for July, 1899, of the Journal of the Military Service Institution, published at Governor's Island, New York Harbor. You will see also that he was not generally complaisant or friendly in his criticisms of other departments, a fact which gives greater weight to his commendatory words concerning the medical service.

Samuer 0. L. Potter, Major and Brigade Surgeon, U. S. V. Attending Surgeon.

Typhoid Fever and Leprosy.

New York Crty, Jan. 20, 1900.

To the Editor: Dr. Alfredo Garces, of Colombia, says: "In places where leprosy reigns it is necessary to avoid the quick changes of temperature which might stop perspiration; such are baths in very cold water, being tired, drafts of cold air when coming from a hot room, or when just awakened, or coming from a dance, or from the neighborhood of a baker's oven, or from the ironing board. Don't live in damp places, especially during confinement, or any other illness, for experience teaches 